\title{
Paleomagnetism of the Patagonian Plateau Basalts, Southern Chile and Argentina
}

Robert F. Butler

Francisco Herve

Francisco Munizaga

Myrl E. BeckJr.

Western Washington University, myrl.beck@wwu.edu

Russ R. Burmester

Western Washington University, russ.burmester@wwu.edu

See next page for additional authors

Follow this and additional works at: https://cedar.wwu.edu/geology_facpubs

Part of the Geology Commons

\section{Recommended Citation}

Butler, Robert F.; Herve, Francisco; Munizaga, Francisco; Beck Jr., Myrl E.; Burmester, Russ R.; and Oviedo, Eduardo S., "Paleomagnetism of the Patagonian Plateau Basalts, Southern Chile and Argentina" (1991). Geology Faculty Publications. 28.

https://cedar.wwu.edu/geology_facpubs/28

This Article is brought to you for free and open access by the Geology at Western CEDAR. It has been accepted for inclusion in Geology Faculty Publications by an authorized administrator of Western CEDAR. For more information, please contact westerncedar@wwu.edu. 
Authors

Robert F. Butler, Francisco Herve, Francisco Munizaga, Myrl E. Beck Jr., Russ R. Burmester, and Eduardo S. Oviedo 


\title{
Paleomagnetism of the Patagonian Plateau Basalts, Southern Chile and Argentina
}

\author{
ROBERT F. BUTLER ${ }^{1}$, FRANCISCO HERVÉ ${ }^{2}$, FRANCISCO MUNIZAGA ${ }^{2}$, MYRL. E. BECK, JR. ${ }^{3}$, \\ RUSSELL F. BURMESTER ${ }^{3}$, AND EDUARDO S. OVIEDO ${ }^{4}$
}

\begin{abstract}
A total of 505 paleomagnetic samples were collected from 65 sites (volcanic flows) of the Patagonian plateau basalts at four locations in southern Chile and Argentina. K/Ar analyses indicate that 38 flows from two locations form a Late Cretaceous group (64-79 Ma), while the remaining 27 flows are Eocene in age $(42-56 \mathrm{Ma})$. Progressive demagnetization indicates that a characteristic remanent magnetization (ChRM) has been successfully isolated from 59 flows. Rock-magnetic properties and analysis of ChRM directions within and between sites allow the secure inference that the ChRM is a thermoremanent magnetization acquired during original cooling. The Eocene flows yield 15 independent samplings of the paleomagnetic field. However, these data fail the reversals test and probably do not adequately average geomagnetic secular variation. The Late Cretaceous flows yield 18 independent samplings of the paleomagnetic field, six of normal polarity and 12 of reversed polarity. These data pass the reversals test and have angular dispersion of virtual geomagnetic poles (VGPs) consistent with adequate sampling of geomagnetic secular variation. The mean of these 18 VGPs yields a Late Cretaceous paleomagnetic pole for South America: latitude $=78.7^{\circ} \mathrm{S}$; longitude $=$ $358.4^{\circ} \mathrm{E} ; A_{95}=6.3^{\circ}\left(K=31.6 ; S=14.5^{\circ}\right)$. This pole is consistent with similar age poles from North America and Africa when the Atlantic is reconstructed to $70 \mathrm{Ma}$. Contrary to previous indications, the South American apparent polar wander path does not reach the present rotation axis until after Late Cretaceous time.
\end{abstract}

\section{INTRODUCTION}

The importance of apparent polar wander (APW) paths for determination of paleogeographic reconstructions and deciphering global tectonics is well known. Determination of APW paths has been a major goal of paleomagnetic research, and numerous techniques for determination, analysis, and interpretation of APW paths have been advanced [Irving and Irving, 1982; Harrison and Lindh, 1982; Gordon et al., 1984]. Analyses of true polar wander and comparisons between alternative plate motion systems require accurate knowledge of APW paths for the major lithospheric plates [Livermore et al., 1984; Gordon and Jurdy, 1986; Gordon and Livermore, 1987]. These analyses have great potential for revealing important elements of plate and mantle dynamics as well as geomagnetic field behavior. However, all such analyses depend critically upon the available paleomagnetic data bases from the major lithospheric plates. Poorly known APW segments are severe detriments to such global syntheses.

In addition to global geodynamics applications, paleomagnetic studies have importance to regional tectonics and have contributed to understanding the tectonic development of western North America [Beck, 1976, 1980; Hillhouse, 1977; Irving, 1979]. In recent years, paleomagnetic studies in Chile and Peru [Kono et al., 1985; Beck et al., 1986; Irwin et al., 1987] have focused on some important problems in Andean tectonic development such as the "Bolivian Orocline" [Beck, 1989]. However, close examination of paleomagnetic

\footnotetext{
'Department of Geosciences, University of Arizona, Tucson.

${ }^{2}$ Departamento de Geología y Geofísica, Universidad de Chile, Santiago.

${ }^{3}$ Department of Geology, Western Washington University, Bellingham.

${ }^{4}$ Departamento de Ciencias Geológicas, Ciudad Universitaria, Buenos Aires, Argentina.
}

Copyright 1991 by the American Geophysical Union.

Paper number $90 \mathrm{JB} 02698$.

$0148-0227 / 91 / 90 \mathrm{JB}-02698 \$ 05.00$ data for cratonal South America suggests that the APW path is poorly constrained for some intervals of geologic time, including the Late Cretaceous and Early Tertiary. Continued progress in using paleomagnetism to decipher patterns of tectonic disturbance in western South America requires improved knowledge of the APW path for the stable continental interior.

Beck et al. [1986] and Beck [1989] discussed the difficulties in defining an adequate Cretaceous paleomagnetic pole for South America. Beck [1989] listed six paleomagnetic poles from Early Cretaceous rocks of South America. Paleomagnetism of the Serra Geral volcanic series ( 130 Ma) has been extensively studied [Bellieni et al., 1983] and the resulting pole $\left(83.8^{\circ} \mathrm{S} ; 94.6^{\circ} \mathrm{E} ; 95 \%\right.$ confidence limit $\left(A_{95}\right)=$ $3.4^{\circ}$ ) must be considered well determined. However, the Late Cretaceous paleomagnetic pole is not well constrained.

For the purposes of this paper, we have examined Late Cretaceous paleomagnetic data from South America using the (minimal) selection criteria of Beck [1989] but adding the requirement that a minimum of five sites (defined as an individual igneous cooling unit or sedimentary bed) must have been sampled. Three paleomagnetic studies pass the selection criteria: (1) Pocos de Caldas (Brazil), age $=77 \mathrm{Ma}$ [Opdyke and MacDonald, 1973]: Five site-mean directions have $95 \%$ confidence limit $\left(\alpha_{95}\right) \leq 20^{\circ}$. The four reversed-polarity sites have an average direction $15^{\circ}$ from the antipode of the single normal-polarity site-mean direction. Although a robust reversals test cannot be performed, the small number of sites cannot provide adequate sampling of geomagnetic secular variation. The paleomagnetic pole calculated from the five sitemean virtual geomagnetic poles (VGPs) is latitude $\left(\lambda_{\mathrm{p}}\right)=$ $84.8^{\circ} \mathrm{S}$; longitude $\left.\left(\phi_{\mathrm{p}}\right)=235.4^{\circ} \mathrm{E} ; A_{95}=10.0^{\circ}\right)$. (2) Las Curtiembres (Argentina), age $=79 \mathrm{Ma}$ [Valencio et al., 1977]: All six sites are of normal polarity so no reversals test is possible. The paleomagnetic pole is $\lambda_{\mathrm{p}}=87.6^{\circ} \mathrm{S}, \phi_{\mathrm{p}}=$ $88.8^{\circ} \mathrm{E} ; A_{95}=12.7^{\circ}$. (3) Cabo de Santo Agostinho (Brazil), age $=94 \mathrm{Ma}$ [Schult and Guerreiro, 1980]: Because the age is within the Cretaceous normal-polarity superchron, all nine sites are normal polarity and no reversals test is possible. The paleomagnetic pole is $\lambda_{\mathrm{p}}=87.7^{\circ} \mathrm{S}, \phi_{\mathrm{p}}=315.1^{\circ} \mathrm{E} ; A_{95}=$ $4.6^{\circ}$. However, the angular standard deviation of site-mean 
VGPs is only $7.1^{\circ}$, which is far less than expected for adequate sampling of geomagnetic secular variation.

The first two poles have large confidence limits because of the small number of sites. For the Cabo de Santo Agostinho pole, the confidence limit $\left(A_{95}=4.6^{\circ}\right)$ is attractively small but probably results from inadequate sampling of geomagnetic secular variation. These three Cretaceous poles differ by $7^{\circ}$ of arc, and their mean is indistinguishable from the present rotation axis. But a Late Cretaceous paleomagnetic pole for South America located at the rotation axis is inconsistent with Cretaceous poles from Africa and North America when finite rotations required to close the Atlantic to Late Cretaceous time are applied. It is thus clear that major problems exist with available Late Cretaceous paleomagnetic data from South America.

The situation for the Early Tertiary of South America is even worse. No paleomagnetic data from Paleogene rocks satisfy the selection criteria. The Late Cretaceous through Early Tertiary portion of the South American APW path thus is obviously a poorly known segment of APW for a major lithospheric plate. We report here results of a paleomagnetic study of the Patagonian Plateau Basalts which greatly increases knowledge of the South American APW path during the Late Cretaceous and Early Tertiary.

\section{Patagonian Plateau Basalts}

\section{Geologic Setting}

The stratigraphic, igneous, and tectonic evolution of Patagonia north of $50^{\circ} \mathrm{S}$ latitude has been summarized by Uliana and Biddle [1987]. The most significant tectonic activity during the Mesozoic and Cenozoic was associated with the Early Cretaceous opening of the South Atlantic Ocean. Lower Mesozoic rocks fill isolated northwest trending basins formed during crustal extension predating the breakup of Gondwana. Seafloor spreading in the South Atlantic commenced at $\sim 130 \mathrm{Ma}$, and subsequent normal faulting in Patagonia has been minor. Across the majority of northern and central Patagonia, Late Cretaceous strata are subhorizontal and are only locally deformed by normal faults of small displacement. Preservation of the northwest trend of Lower Mesozoic basins indicates that possible vertical-axis tectonic rotations which may have affected the Tierra del Fuego region have not affected northern or central Patagonia.

The Patagonian plateau basalts are a sequence of flat-lying Late Cretaceous through Tertiary basaltic and andesitic rocks exposed east of the Andes in dissected mesetas of Chilean and Argentine Patagonia. The plateau basalts cover a total area of $120,000 \mathrm{~km}^{2}$ between $40^{\circ} \mathrm{S}$ and $52^{\circ} \mathrm{S}$. The general geologic setting, petrology, and reconnaissance radiometric dating of the Patagonian plateau basalts were reported by Baker et al. [1981] and Ramos et al. [1982]. These igneous rocks are situated east of the Andes and rest on generally flat-lying older Mesozoic silicic volcanic or sedimentary rocks. Of major importance to the paleomagnetic investigation is the lack of significant tectonic disturbance of this portion of Patagonia from Late Cretaceous to present.

Guided by the previous work of Baker et al. [1981] and Ramos et al. [1982], our investigations centered on the major sequences of Late Cretaceous and Early Tertiary rocks of the Patagonian plateau basalts. Figure 1 is an index map of the region from which our sample collections of the Patagonian plateau basalts were obtained.

\section{Field Sampling}

Samples for paleomagnetic and radioisotopic (K/Ar) analyses of the Patagonian plateau basalts were collected at four

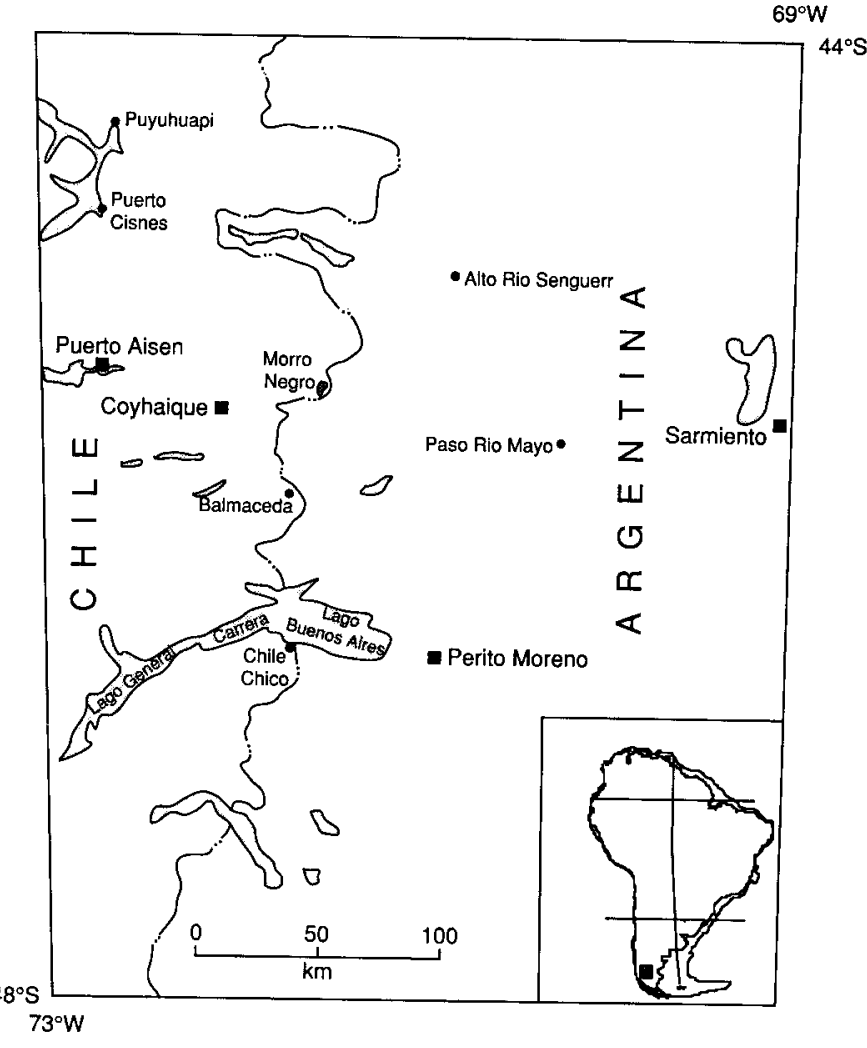

Fig. 1. Index map of Argentine and Chilean Patagonia between $44^{\circ} \mathrm{S}$ and $48^{\circ} \mathrm{S}$. Intemational border is indicated by alternating solid and dotted line.

locations: west of Alto Rio Senguerr in Argentina; at Morro Negro; northwest of Balmaceda; and at Cerro Lápiz southwest of Chile Chico in Chile (Figure 1). At all locations, the flows are essentially flat-lying; separate flows generally can be distinguished by brecciated and reddened zones at their base.

Paleomagnetic sampling employed standard coring techniques with 5-11 cores collected from each flow (paleomagnetic site). An orientation stage with inclinometer, magnetic compass, and solar compass was used for core orientation. Effects of lightning strikes were sometimes indicated by differences between magnetic and solar compass azimuths. To avoid collection of lightning-struck regions of flows, outcrops were surveyed with magnetic compass to detect areas which produced significant deflections. These areas were avoided during sample collection. When discrepancies occurred between azimuths determined by solar compass and magnetic compass, the azimuth determined by solar compass was used.

At the locality west of Alto Rio Senguerr, paleomagnetic samples were collected from two stratigraphic sections separated by about $7 \mathrm{~km}$. Mean site location was $45.07^{\circ} \mathrm{S}$, $288.97^{\circ} \mathrm{E}$. Eight samples were collected from each of the 17 sites, and all samples were oriented with both magnetic and solar compass. Although solar compass and magnetic compass azimuths were generally within $3^{\circ}$, differences (up to $56^{\circ}$ ) indicated that some outcrops had been exposed to lightning strikes. Indeed lightning-induced components of magnetization were found in numerous samples from the Alto Rio Senguerr locality. Five samples were collected for K/Ar analysis.

Paleomagnetic samples were collected from a succession of 17 flows on the north slope of Morro Negro adjacent to the 
Chile-Argentina border $\left(45.48^{\circ} \mathrm{S}, 288.52^{\circ} \mathrm{E}\right)$. In addition, samples were collected from two sites $10 \mathrm{~km}$ north of Morro Negro and from two sites $4 \mathrm{~km}$ west of Morro Negro. Of the total 152 samples from the Morro Negro area, 84 were oriented with solar compass. Magnetic and solar azimuths for most samples were within $3^{\circ}$. Even for sites at the top of Morro Negro, differences in magnetic and solar azimuths were always $<5^{\circ}$. Five samples were collected for K/Ar analysis.

Twelve sites were collected from three sections at a location $\left(45.88^{\circ} \mathrm{S}, 288.25^{\circ} \mathrm{E}\right)$ near Balmaceda, Chile (Figure 1) Of the 98 samples from this location, 73 were oriented with solar compass. Magnetic and solar azimuths generally agreed within $3^{\circ}$, but differences up to $9^{\circ}$ were noted for a few samples. A single sample for $\mathrm{K} / \mathrm{Ar}$ analysis was collected from the Balmaceda area. At Cerro Lápiz $\left(46.58^{\circ} \mathrm{S}, 288.13^{\circ} \mathrm{E}\right)$ southwest of Chile Chico, 15 sites were collected from two sections (Figure 1). Of the 119 total samples from Cerro Lápiz, 100 were oriented with solar compass; again mos magnetic and solar azimuths were within $3^{\circ}$ with rare differences reaching $8^{\circ}$. Three samples were collected from this area for $\mathrm{K} / \mathrm{Ar}$ analysis.

\section{K/Ar ANALYSES}

All argon analyses were performed on whole rock samples because of difficulty in separating appropriate plagioclase quantities. Granules of 35-60 mesh size were used to optimize homogeneity of the fraction analyzed for $\mathrm{Ar}$ and $\mathrm{K}$. Argon analyses were carried out at the Natural Environment Research Council's Isotope Geology Center (London, United Kingdom) under the guidance of C. Rundle. Argon was extracted by fusion in ultrahigh vacuum using RF induction heating and analyzed by the isotope dilution method on a VG MM 1200 on-line mass spectrometer. Potassium content was determined by atomic absorption at the Servicio Nacional de Geología y Minería (Santiago, Chile). Analytical data for determination of K/Ar dates are given in Table 1 . The analytical errors for the K/Ar age determinations were computed by

TABLE 1. K/Ar Analytical Data

\begin{tabular}{ccccc}
\hline Sample & $\mathrm{K}$, & ${ }^{40} \mathrm{Ar} \mathrm{rad}$, & ${ }^{40} \mathrm{Ar}$ atm, & Age $\pm 2 \sigma$, \\
& $\%$ & $\mathrm{nl} / \mathrm{g}$ & $\%$ & $\mathrm{Ma}$
\end{tabular}

\begin{tabular}{lrrrr} 
MNO-7 & 0.84 & 2.30 & 47 & $69.2 \pm 2.6$ \\
MNO-5 & 0.58 & 1.48 & 54 & $64.2 \pm 2.6$ \\
MNO-2 & 2.19 & 6.07 & 25 & $69.8 \pm 2.3$ \\
MNO-1 & 1.89 & 5.68 & 13 & $75.5 \pm 2.4$ \\
SLL-464* & 0.53 & 1.61 & 75 & $76.1 \pm 5.3$ \\
SLL-468** & 3.53 & 10.94 & 49 & $77.3 \pm 2.9$ \\
RS-012 & 1.16 & 3.64 & 63 & $78.9 \pm 4.4$ \\
RS-016 & 1.10 & 3.47 & 66 & $79.1 \pm 4.7$ \\
RS-002 & 1.44 & 4.23 & 57 & $74.3 \pm 4.6$ \\
RS-008 & 1.20 & 3.49 & 74 & $73.6 \pm 5.4$ \\
RS-010 & 1.05 & 2.64 & 81 & $63.9 \pm 6.3$ \\
BA-012 & 1.15 & 2.53 & 63 & $55.6 \pm 3.1$ \\
CL-002 & 0.63 & 1.04 & 84 & $42.0 \pm 4.5$ \\
CL-008 & 0.85 & 1.59 & 68 & $47.7 \pm 3.0$ \\
CL-008† & 0.85 & 1.62 & 80 & $48.5 \pm 4.5$ \\
CL-009 & 1.06 & 2.14 & 72 & $51.1 \pm 3.5$ \\
\hline
\end{tabular}

All analyses are for whole rock samples. Decay and abundance constants of Steiger and Jager [1977] were used for calculations of isotopic ages.

* Dyke sample

** Dacite sample from $2 \mathrm{~km}$ north of Morro Negro.

$\dagger$ Repeat analysis of sample CL-008. combining the standard errors determined for the isotope ratio measurement, the spike volume, and the potassium content determinations. They represent estimates of the analytical precision only and are quoted at the $2 \sigma$ confidence level.

In general, $\mathrm{K} / \mathrm{Ar}$ dates are considered minimum ages representing the time since cooling below temperatures of argon retention in potassium-bearing minerals. Because of rapid cooling, K/Ar dates for volcanic rocks are essentially the age of crystallization. However, later heating events can alter the ${ }^{40} \mathrm{~K}-{ }^{40} \mathrm{Ar}$ system and complicate interpretations. Results are presented in Table 1 and are discussed below by locality:

Morro Negro. The K/Ar dates from extrusive rocks of this location range from $64.2 \pm 2.6 \mathrm{Ma}$ to $76.1 \pm 5.3 \mathrm{Ma}$. However, the dates do not correlate with stratigraphic position, suggesting that analytical errors overestimate the accuracy of age determinations. Note that samples MN0-1, MNO2 , and MNO-7 have similar ages but different contents of $\mathrm{K}$ and atmospheric Ar. This observation strongly suggests that no radiogenic Ar was inherited by these samples. The $\mathrm{K} / \mathrm{Ar}$ age of sample MNO-5 (64 $\pm 2.6 \mathrm{Ma}$ ) appears anomalously young and could be due to zeolites and chalcedony that fill vesicles. The average age of samples MN0-1, MNO-2, and MNO-7 is $71.4 \pm 5 \mathrm{Ma}$ and most likely represents the crystallization age of the volcanic sequence. Note that this average age is consistent with the age of the dyke sample (SLL-464) and the age of the dacite sample (SLL-468) collected $2 \mathrm{~km}$ north of the main volcanic sequence at Morro Negro.

Alto Rio Senguerr. The K/Ar data for samples RS-008, RS-002, RS-016, and RS-012 indicate that the dates range from $73.6 \pm 5.4 \mathrm{Ma}$ to $79.1 \pm 4.7 \mathrm{Ma}$. These samples have a high percentage of atmospheric Ar, and the ages are within analytical error. Sample RS-010 yields an age which appears anomalously young considering its stratigraphic position below samples RS-002 and RS-008. The ages obtained at Rio Senguerr and at Morro Negro are concordant with the data obtained by Baker et al. [1981] on rocks from the Balmaceda to Lago La Plata region (81-77 Ma).

Cerro Lápiz and Balmaceda. The single K/Ar date from the volcanic sequence at Balmaceda is $55.6 \pm 3.1 \mathrm{Ma}$. Within the volcanic sequence at Cerro Lápiz, there is concordance between K/Ar dates and stratigraphic position. The dated samples at this location have ages similar to the lower basalts of the Meseta Buenos Aires; an 200-m-thick sequence of porphyritic basaltic flows with average age of 52 Ma which overlie Upper Cretaceous and Paleocene marine sediments [Charrier et al., 1978, 1979]. At both Balmaceda and Cerro Lápiz, the $\mathrm{K} / \mathrm{Ar}$ analyses indicate early to middle Eocene ages.

\section{ROCK MAGNETIC ANALYSIS}

Strong-field thermomagnetic analyses on representative samples were performed with the instrument described by Galbrun and Butler [1986]. The results shown in Figure $2 a$ are typical for samples from Morro Negro and Alto Rio Senguerr. The dominant Curie temperature $\left(T_{c}\right)$ is $580^{\circ} \mathrm{C}$ suggesting that magnetite is the dominant ferrimagnetic mineral. Figure $2 b$ illustrates typical thermomagnetic behavior for samples from Balmaceda and Cerro Lápiz. Two Curie temperatures are observed: one at $-300^{\circ} \mathrm{C}$ indicating the presence of an intermediate composition $(x \approx 0.4)$ titanomagnetite and another at $\sim 550^{\circ} \mathrm{C}$ indicating $\mathrm{Ti}$-poor titanomagnetite. The observed differences in mineralogy of the ferrimagnetic minerals are most likely the result of varying degrees of deuteric oxidation.

Coercivity-spectrum analysis examined acquisition and subsequent thermal demagnetization of isothermal remanent magnetism (IRM) for representative samples [Dunlop, 1972; Lowrie and Heller, 1982]. Example results are shown in 

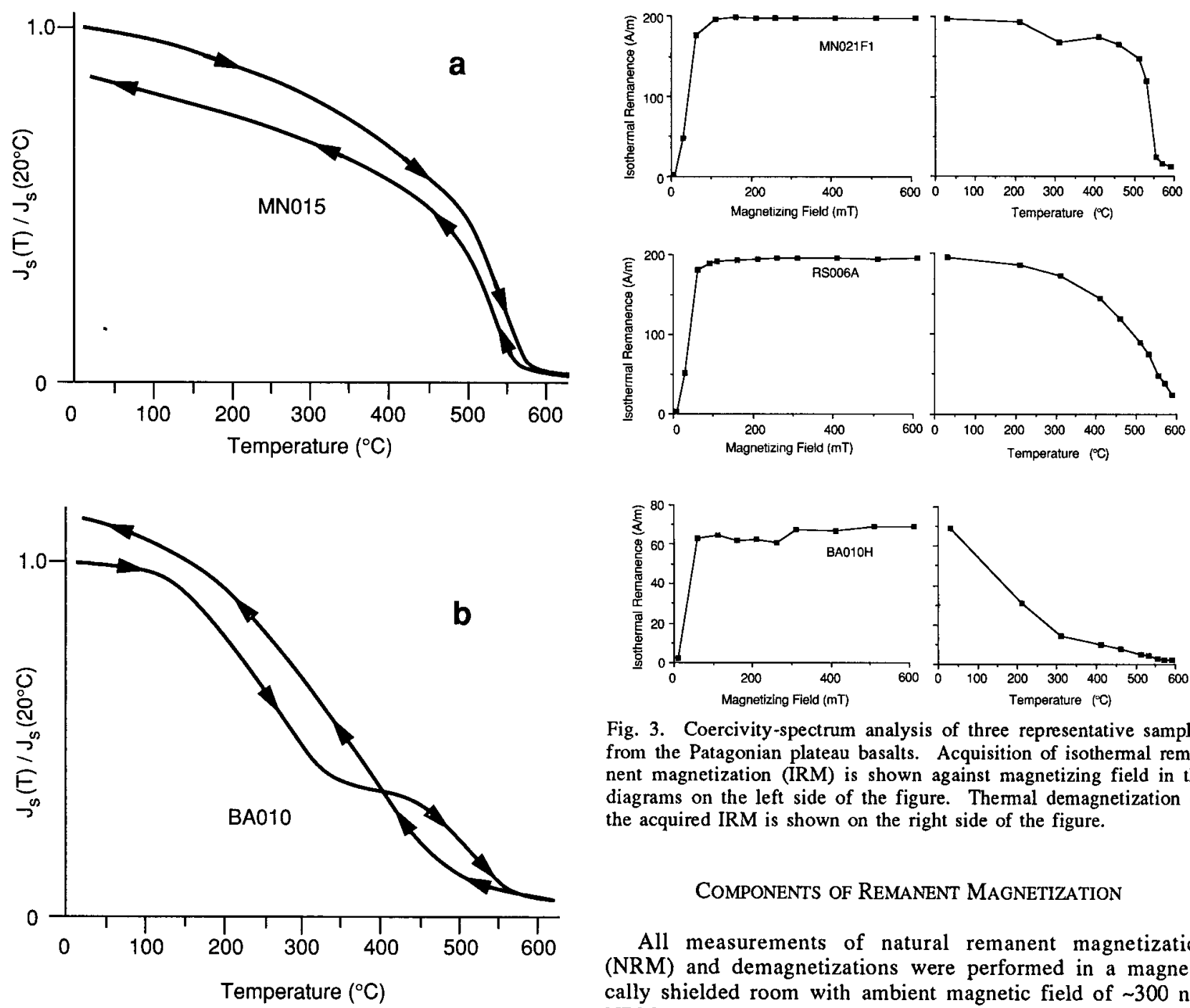

Fig. 3. Coercivity-spectrum analysis of three representative samples from the Patagonian plateau basalts. Acquisition of isothermal remanent magnetization (IRM) is shown against magnetizing field in the diagrams on the left side of the figure. Thermal demagnetization of the acquired IRM is shown on the right side of the figure.

\section{COMPONENTS OF REMANENT MAGNETIZATION}

All measurements of natural remanent magnetization (NRM) and demagnetizations were performed in a magnetically shielded room with ambient magnetic field of $\sim 300 \mathrm{nT}$. NRM was measured with a two-axis cryogenic magnetometer or a digital spinner magnetometer. Alternating field (AF)

Fig. 2. Strong-field thermomagnetic behaviors of samples from two representative sites. Magnetization in applied field of $200 \mathrm{mT}$ (normalized to room temperature value) is shown against temperature. (a) Sample with a single Curie temperature of $\sim 575^{\circ} \mathrm{C}$; typical of behaviors for samples from Morro Negro and Alto Rio Senguerr. (b) Curie temperatures of $-325^{\circ} \mathrm{C}$ and $\sim 575^{\circ} \mathrm{C}$ are observed in the heating curve of this sample from Balmaceda. The majority of samples from Balmaceda and Cerro Lápiz contained a ferrimagnetic phase with Curie temperature in the $300^{\circ}-350^{\circ} \mathrm{C}$ interval.

Figure 3. IRM was acquired entirely below $200 \mathrm{mT}$ magnetizing field, consistent with magnetite or titanomagnetite as the dominant ferrimagnetic mineral. Subsequent thermal demagnetization of IRM showed blocking temperatures for samples from Morro Negro and Alto Rio Senguerr dominantly within $100^{\circ} \mathrm{C}$ of the $580^{\circ} \mathrm{C}$ Curie temperature for magnetite. Blocking temperatures of IRM for samples from Balmaceda and Cerro Lápiz were dominantly below $300^{\circ} \mathrm{C}$ but with a minor portion of IRM displaying blocking temperatures up to $580^{\circ} \mathrm{C}$. These observations of IRM acquisition and thermal demagnetization are entirely consistent with the strong-field thermomagnetic analyses.

These rock-magnetic data are typical of subaerial basalts with magnetite or titanomagnetite as the dominant ferrimagnetic mineral and with varying degrees of deuteric oxidation. There is no indication that hematite or titanohematite are present in significant abundance. demagnetization was performed with a tumbling specimen demagnetizer and thermal demagnetization used a mu-metal shielded furnace with magnetic field $<15 \mathrm{nT}$ in the specimen region.

Intensities of NRM ranged from 0.11 to $99 \mathrm{~A} / \mathrm{m}$ with major variation within the collections from each of the four sampling locations. NRM directions showed a general grouping about the anticipated normal and reversed polarity directions. Superposed streaking of NRM directions toward the present magnetic field direction indicated the presence of viscous magnetization in some samples. Lighting-induced IRM components were apparent in some samples, indicated by aberrant NRM directions and anomalously high NRM intensity.

To examine coercive force and blocking temperature spectra of the NRM, progressive AF and thermal demagnetization experiments were performed on a representative set of samples. Comparison of $\mathrm{AF}$ and thermal demagnetization results was facilitated by examining one sample from a chosen site using AF demagnetization, while another sample from the same site was subjected to thermal demagnetization. Two samples from each of 45 sites were progressively demagnetized. Progressive AF demagnetization used 10 steps to maximum peak AF of $80 \mathrm{mT}$, while progressive thermal demagnetization was usually done in 10 steps to maximum temperature of $600^{\circ} \mathrm{C}$. Results were analyzed with the aid of principal component analysis [Kirschvink, 1980]. 
a

MN010A1 AFdemag

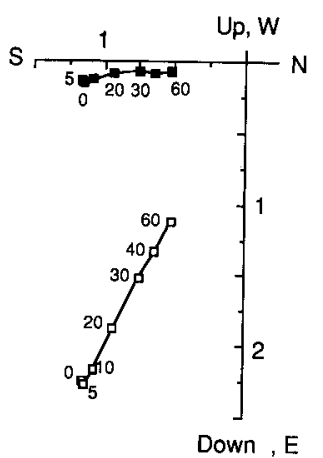

Down, E

RS001H AFdemag

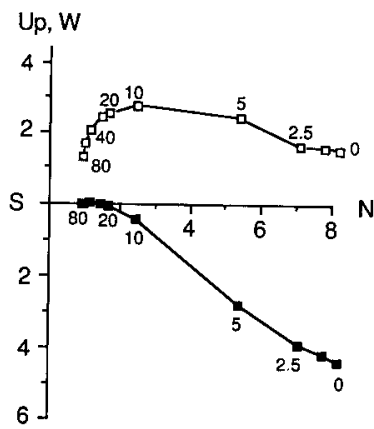

Down, $E$ b

MN010A2 Thermal Demag

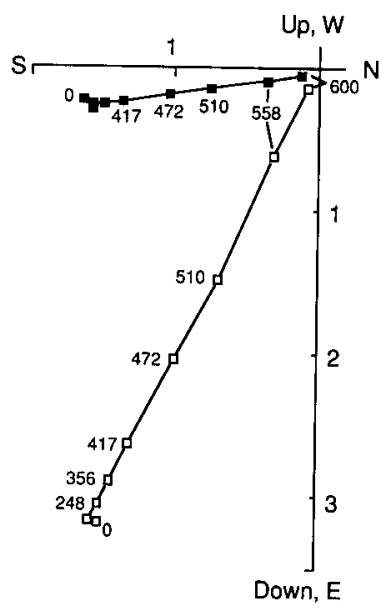

d

RS002B Thermal demag

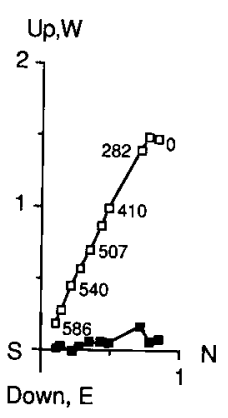

which is within $3^{\circ}$ of the best fit line to the thermal demagnetization data of the companion sample (Figure $4 b$ ).

For some paired samples, the ChRM directions determined by $\mathrm{AF}$ and thermal demagnetization were significantly different (Figures $5 a$ and $5 b$ ), but the differences rarely exceed $5^{\circ}$ and were not systematic from site to site. Therefore, either AF demagnetization to peak fields in the $10-40 \mathrm{mT}$ interval or thermal demagnetization to temperatures $\geq 200^{\circ} \mathrm{C}$ were usually successful in isolating the ChRM. In addition to the rock-magnetic data presented above, the NRM coercivity and blocking temperature spectra indicate that the ChRM is carried by magnetite or titanomagnetite. Along with the analyses below, these data strongly indicate that the ChRM is a primary TRM acquired during original cooling of these volcanic rocks.

Large secondary components of NRM with coercivity dominantly $<20 \mathrm{mT}$ were encountered in some samples (Figure $4 c$ ). These samples had anomalously high NRM intensity and aberrant direction, indicating that the secondary component is lightning-induced IRM. This interpretation is supported by occurrence of these samples in sites where solar and magnetic compass azimuths were divergent. In almost all cases, $\mathrm{AF}$ demagnetization to $20 \mathrm{mT}$ was sufficient to remove these secondary components, isolating the ChRM direction.

Samples from four sites (CL004-CL007) collected at Cerro Lápiz had anomalously low NRM intensities and scattered directions. Erratic results were obtained during both $\mathrm{AF}$ and thermal demagnetization (Figure $5 c$ ) and neither procedure satisfactorily isolated a ChRM from these sites. Samples from these sites were dropped from further consideration.

Because of the equivalence of $\mathrm{AF}$ and thermal demagnetization in isolating the ChRM and the relative ease of $\mathrm{AF}$ demagnetization, remaining samples were treated with $\mathrm{AF}$ demagnetization. To allow principal component analysis, each sample was demagnetized in three to four peak fields from 10 to $40 \mathrm{mT}$. Estimates of the ChRM direction for

Fig. 4. Vector component diagrams of progressive demagnetization of natural remanent magnetization (NRM) for samples from Morro Negro and Alto Rio Senguerr. Open squares indicate projection of the NRM vector onto the vertical plane, while solid squares indicate projections onto the horizontal plane. Results of alternating field (AF) demagnetization are shown in diagrams labeled "AF demag," while results of thermal demagnetization are shown in diagrams labeled "Thermal demag." Numbers adjacent to data points indicate peak AF (in milliteslas) for AF demagnetization or temperature (in degrees celsius) for thermal demagnetization.

Example vector demagnetization diagrams are shown in Figures 4 and 5. Many samples displayed little or no evidence of secondary components of NRM (Figures $4 a$ and $4 b$ ). $A$ trend toward the origin was almost always established during $A F$ demagnetization to peak fields $\geq 10$ or $20 \mathrm{mT}$, indicating isolation of the characteristic remanent magnetization (ChRM) at these levels. The majority of the NRM coercivity spectrum is below the maximum peak AF of $80 \mathrm{mT}$, and blocking temperatures are almost entirely below $580^{\circ} \mathrm{C}$. Several samples from Balmaceda and Cerro Lápiz showed blocking temperatures entirely below $300^{\circ} \mathrm{C}$ consistent with the rock-magnetic data indicating the dominance of intermediate composition titanomagnetite in some of these flows.

Generally, the ChRM direction isolated by thermal demagnetization to temperatures $>200^{\circ} \mathrm{C}$ was indistinguishable from that isolated during AF demagnetization. For example, principal component analysis yields a best fit line to the progressive $\mathrm{AF}$ demagnetization data of Figure $4 a$

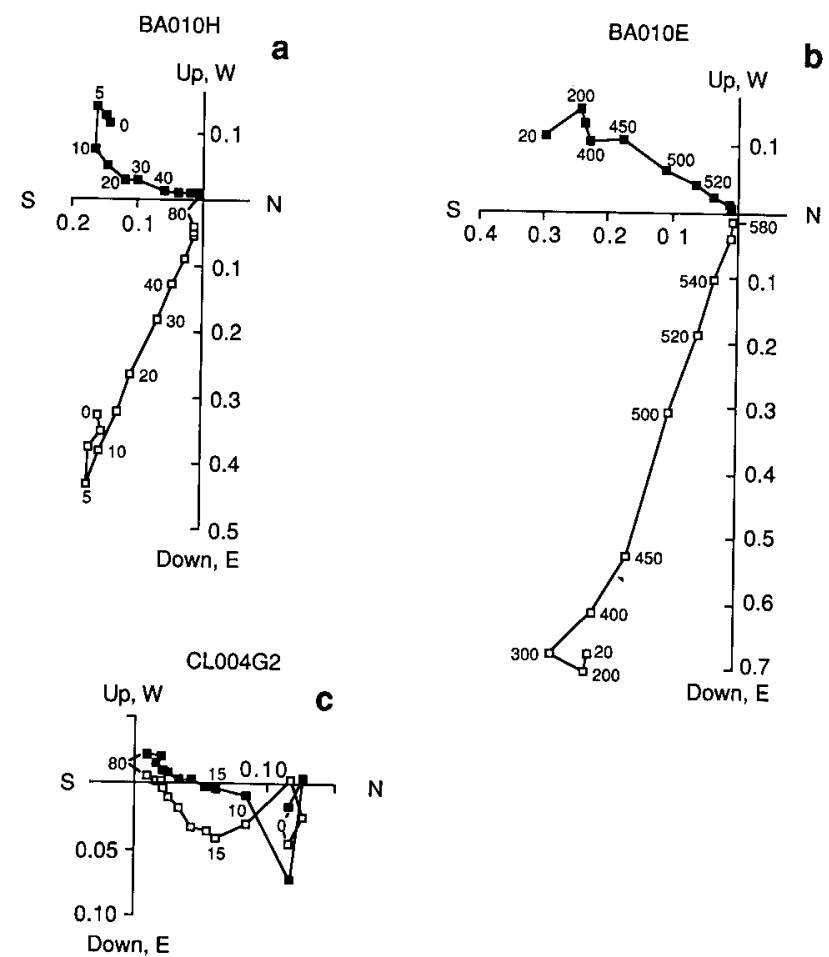

Fig. 5. Vector component diagrams of progressive demagnetization of natural remanent magnetization (NRM) for samples from Balmaceda and Cerro Lápiz. Conventions are same as for Figure 4. 
each sample were determined by three modes of line-fitting analysis: (1) "free" lines were fit to the demagnetization data only; (2) "origin" lines were fit by adding the origin of the vector demagnetization diagram as an equally weighted datum; and (3) "anchored" lines were fit by constraining the best fit line to pass through the origin. In almost all cases, ChRM directions determined by these different techniques are within $5^{\circ}$ (most within $2^{\circ}$ ), although the maximum angular deviation was usually less for origin or anchored lines than for free lines. These results attest to the general high precision with which the sample ChRM directions can be determined and the insensitivity of the results to the method of analysis.

To determine site-mean ChRM directions from the sample ChRM directions, several options were explored. Site-mean ChRM directions (and associated statistics) were calculated using the method of Fisher [1953] with the following determinations of sample ChRM directions used as input: (1) ChRM directions determined by the three modes of line fits discussed above; and (2) ChRM directions at each individual
AF demagnetization level. With this procedure, six or seven methods of determining the site-mean ChRM direction were compared.

As with the analysis of sample ChRM directions, calculated site-mean ChRM directions were insensitive to the method of determination. For almost all sites, the above methods yielded site-mean ChRM directions which were statistically indistinguishable. Given little reason to choose between the various modes of analysis, we have simply chosen the determination of site-mean ChRM which maximizes $k$ (estimate of Fisher's precision parameter). These "best" site-mean ChRM directions are listed in Table 2, along with the method of determination, statistics, and site-mean virtual geomagnetic pole (VGP). The general high quality of the data is indicated by the small $95 \%$ confidence limits $\left(\alpha_{95}\right)$ and high $k$ for site-mean ChRM directions. Fifty-five of the 61 site means have $\alpha_{95}<5^{\circ}$.

As with most paleomagnetic investigations, there were some samples and a few entire sites which did not yield

TABLE 2. Site-Mean Directions of ChRM

\begin{tabular}{|c|c|c|c|c|c|c|c|c|c|c|}
\hline Site & $N / N_{\mathrm{o}}$ & Demag & $N^{\prime}$ & $\begin{array}{c}I_{m} \\
\text { deg }\end{array}$ & $\begin{array}{c}D_{m} \\
\operatorname{deg}\end{array}$ & $\begin{array}{l}\alpha_{95} \\
\operatorname{deg}\end{array}$ & $R$ & $k$ & $\begin{array}{c}\lambda_{\mathrm{p}} \\
{ }^{\circ} \mathrm{N}\end{array}$ & $\begin{array}{l}\phi_{\mathrm{p}} \\
{ }^{\circ} \mathrm{E}\end{array}$ \\
\hline MN001 & $10 / 10$ & ALine & 4 & 59.9 & 147.1 & 3.5 & 9.95 & 191.1 & -65.7 & 17.8 \\
\hline MN002 & $6 / 6$ & Aline & 4 & 54.7 & 171.3 & 2.7 & 5.99 & 613.2 & -77.8 & 72.7 \\
\hline MN003 & $5 / 5$ & Aline & 4 & 53.3 & 171.2 & 4.6 & 4.99 & 280.6 & -76.2 & 75.2 \\
\hline MN004 & $4 / 5$ & Aline & 4 & 55.5 & 168.8 & 2.7 & 4.00 & 1157.6 & -77.3 & 63.0 \\
\hline MN005 & $5 / 5$ & Aline & 4 & 56.8 & 170.3 & 1.7 & 5.00 & 1942.7 & -79.1 & 63.1 \\
\hline \multirow[t]{2}{*}{ MN006 } & $6 / 6$ & Aline & 4 & 56.9 & 172.2 & 3.4 & 5.99 & 383.8 & -80.1 & 69.8 \\
\hline & $5^{*}$ & & & 55.0 & 170.8 & 1.8 & 5.00 & 1746.0 & -77.8 & 70.3 \\
\hline MN007 & $6 / 6$ & Aline & 4 & 62.4 & 169.1 & 1.8 & 6.00 & 1407.7 & -82.0 & 27.8 \\
\hline MNO08 & $5 / 5$ & Aline & 4 & 59.2 & 167.1 & 3.7 & 4.99 & 424.5 & -79.0 & 44.0 \\
\hline MN009 & $6 / 6$ & Aline & 4 & 63.3 & 173.2 & 2.3 & 5.99 & 822.5 & -85.2 & 23.6 \\
\hline MN010 & $6 / 6$ & Aline & 4 & 62.4 & 170.6 & 2.2 & 5.99 & 900.3 & -83.1 & 30.0 \\
\hline MN011 & $6 / 6$ & Aline & 4 & 62.6 & 170.0 & 2.5 & 5.99 & 693.3 & -82.7 & 27.4 \\
\hline \multirow[t]{2}{*}{ MN012 } & $4 / 4$ & Aline & 4 & 60.6 & 168.4 & 3.0 & 4.00 & 946.9 & -80.8 & 39.5 \\
\hline & 6* & & & 61.7 & 169.6 & 1.5 & 6.00 & 2057.2 & -82.1 & 34.1 \\
\hline MN014 & $8 / 8$ & Aline & 4 & 64.6 & 160.7 & 2.7 & 7.98 & 431.2 & -76.6 & 7.2 \\
\hline MN015 & $9 / 10$ & Aline & 4 & 76.2 & 183.4 & 1.1 & 9.00 & 2389.2 & -71.5 & 283.8 \\
\hline MN017 & $6 / 6$ & Aline & 4 & -73.9 & 336.8 & 1.9 & 6.00 & 1181.9 & 70.0 & 143.7 \\
\hline MN018 & $4 / 4$ & Aline & 4 & -67.3 & 330.1 & 2.5 & 4.00 & 1311.1 & 69.5 & 174.6 \\
\hline $\mathrm{MNO} 20$ & $6 / 6$ & Aline & 4 & 60.8 & 147.6 & 7.9 & 5.93 & 73.1 & -66.5 & 15.9 \\
\hline MN021 & $5 / 6$ & Aline & 4 & 56.1 & 133.5 & 3.5 & 4.99 & 466.0 & -54.3 & 16.0 \\
\hline \multirow[t]{2}{*}{$\mathrm{MN022}$} & $6 / 6$ & Aline & 4 & 58.3 & 139.8 & 6.5 & 5.95 & 108.8 & -59.8 & 16.5 \\
\hline & $2^{*}$ & & & 57.2 & 136.5 & 6.5 & 2.00 & 108.8 & -57.0 & 16.3 \\
\hline $\mathrm{MN023}$ & $7 / 7$ & Aline & 4 & 58.9 & 161.5 & 3.5 & 6.98 & 300.4 & -75.2 & 35.2 \\
\hline MN024 & $7 / 7$ & Aline & 4 & 60.2 & 151.6 & 2.6 & 6.99 & 524.1 & -69.0 & 20.3 \\
\hline RS001 & $6 / 7$ & $A F=40$ & & -59.9 & 359.2 & 4.3 & 5.98 & 242.0 & 85.7 & 281.1 \\
\hline RSO02 & $7 / 7$ & $\mathrm{AF}=40$ & & -62.6 & 355.9 & 6.1 & 6.94 & 99.3 & 86.9 & 219.0 \\
\hline \multirow[t]{2}{*}{ BSO03 } & $8 / 8$ & Aline & 3 & -53.7 & 3.7 & 14.8 & 7.53 & 15.0 & 78.8 & 304.8 \\
\hline & $3^{*}$ & & & -58.7 & 359.9 & 7.6 & 2.99 & 263.6 & 84.4 & 288.5 \\
\hline RSO04 & $7 / 7$ & $A F=40$ & & 79.8 & 164.2 & 2.6 & 6.99 & 550.9 & -63.7 & 301.0 \\
\hline RSO05 & $7 / 7$ & $A F=10$ & & 77.7 & 166.2 & 2.1 & 6.99 & 821.7 & -67.3 & 303.3 \\
\hline RS006 & $8 / 8$ & $A F=10$ & & 77.5 & 171.6 & 2.1 & 7.99 & 689.2 & -68.5 & 298.3 \\
\hline \multirow[t]{2}{*}{ RS007 } & $8 / 8$ & $A F=10$ & & 78.4 & 170.2 & 2.0 & 7.99 & 771.0 & -66.7 & 298.4 \\
\hline & $4 *$ & & & 78.4 & 168.2 & 1.4 & 4.00 & 4288.6 & -66.6 & 300.3 \\
\hline RS008 & $6 / 7$ & Oline & 3 & 74.3 & 175.1 & 1.6 & 6.00 & 1796.7 & -74.2 & 297.8 \\
\hline RS009 & $7 / 8$ & Oline & 3 & 75.9 & 180.5 & 2.0 & 6.99 & 943.3 & -71.7 & 288.2 \\
\hline RS010 & $7 / 7$ & $A F=10$ & & 74.5 & 175.0 & 2.2 & 6.99 & 747.3 & -73.9 & 296.7 \\
\hline \multirow[t]{2}{*}{ RS011 } & $6 / 7$ & Aline & 3 & 77.2 & 183.1 & 4.3 & 5.98 & 245.3 & -69.4 & 285.4 \\
\hline & $4^{*}$ & & & 75.5 & 178.3 & 1.9 & 4.00 & 2330.6 & -72.4 & 291.6 \\
\hline RS012 & $7 / 7$ & Aline & 3 & -60.9 & 356.2 & 2.4 & 6.99 & 638.4 & 85.9 & 246.0 \\
\hline RS013 & $8 / 8$ & $\mathrm{AF}=10$ & & -56.4 & 357.5 & 1.3 & 8.00 & 1841.5 & 81.7 & 274.9 \\
\hline RS014 & $8 / 8$ & $\mathrm{AF}=40$ & & -58.5 & 350.5 & 2.8 & 7.98 & 391.8 & 80.8 & 235.5 \\
\hline RS015 & $8 / 8$ & $\mathrm{AF}=40$ & & -59.7 & 352.0 & 1.5 & 7.99 & 1360.3 & 82.6 & 233.7 \\
\hline \multirow[t]{2}{*}{ RS016 } & $6 / 7$ & Aline & 3 & -59.2 & 354.2 & 1.5 & 6.00 & 1916.6 & 83.4 & 246.8 \\
\hline & $3 *$ & & & -59.1 & 352.2 & 1.7 & 3.00 & 4990.3 & 82.3 & 238.1 \\
\hline RS017 & $7 / 7$ & $A F=30$ & & 76.1 & 181.8 & 2.2 & 6.99 & 779.6 & -71.3 & 286.6 \\
\hline
\end{tabular}


TABLE 2. (continued)

\begin{tabular}{|c|c|c|c|c|c|c|c|c|c|c|}
\hline Site & $N / N_{\mathrm{o}}$ & Demag & $N^{\prime}$ & $\begin{array}{l}I_{m}, \\
\mathrm{deg}\end{array}$ & $\begin{array}{l}D_{m}, \\
\operatorname{deg}\end{array}$ & $\begin{array}{l}\alpha_{95} \\
\text { deg }\end{array}$ & $R$ & $k$ & $\begin{array}{c}\lambda_{\mathrm{p}}, \\
{ }^{\circ} \mathrm{N}\end{array}$ & ${ }_{\mathrm{p}}$, \\
\hline $\mathrm{BAO01}$ & $7 / 7$ & $A F=20$ & 3 & 67.0 & 145.8 & 1.9 & 6.99 & 1044.1 & -66.9 & 356.2 \\
\hline $\mathrm{BA} 002$ & $8 / 8$ & Aline & 3 & 67.3 & 161.0 & 2.5 & 7.99 & 492.9 & -76.7 & 353.0 \\
\hline $\mathrm{BA003}$ & $8 / 8$ & $\mathrm{AF}=30$ & & 75.7 & 165.2 & 4.5 & 7.95 & 149.9 & -71.0 & 309.1 \\
\hline BA004 & $9 / 9$ & $A F=20$ & & 65.1 & 155.6 & 2.9 & 8.97 & 306.3 & -73.2 & 5.0 \\
\hline BA005 & $7 / 7$ & Aline & 3 & 69.1 & 133.9 & 2.1 & 6.99 & 821.2 & -59.7 & 348.5 \\
\hline BA006\# & $4 / 6$ & Aline & 3 & 76.9 & 154.0 & 23.0 & 3.82 & 16.9 & & \\
\hline BA007 & $8 / 8$ & $\mathrm{AF}=30$ & & 76.2 & 153.8 & 3.3 & 7.97 & 277.4 & -66.9 & 318.1 \\
\hline BA008 & $6 / 7$ & Oline & 3 & 68.7 & 147.5 & 3.9 & 5.98 & 292.0 & -68.0 & 350.2 \\
\hline \multirow[t]{2}{*}{ BA009 } & $8 / 8$ & Aline & 3 & 73.4 & 144.2 & 5.0 & 7.94 & 122.8 & -64.9 & 333.3 \\
\hline & $2^{*}$ & & & 71.0 & 146.0 & 5.0 & 2.00 & 561.5 & -66.7 & 341.6 \\
\hline BA010 & $7 / 7$ & $\mathrm{AF}=30$ & & 70.9 & 189.2 & 2.4 & 6.99 & 628.0 & -79.0 & 259.9 \\
\hline BA011 & $8 / 8$ & $A F=20$ & & 68.0 & 203.8 & 2.6 & 7.98 & 457.9 & -73.5 & 225.7 \\
\hline \multirow[t]{2}{*}{ BA012 } & $8 / 8$ & $\mathrm{AF}=40$ & & 65.1 & 205.7 & 3.3 & 7.98 & 282.8 & -72.4 & 211.7 \\
\hline & $2^{*}$ & & & 66.6 & 204.8 & 3.3 & 2.00 & 1381.8 & -73.0 & 218.3 \\
\hline CLOO1 & $7 / 7$ & $\mathrm{AF}=20$ & & -65.8 & 345.6 & 3.8 & 6.98 & 250.4 & 80.1 & 184.5 \\
\hline \multirow[t]{2}{*}{ CLOO2 } & $7 / 7$ & Oline & 3 & -68.9 & 340.1 & 4.6 & 6.96 & 170.6 & 75.9 & 167.0 \\
\hline & $2^{*}$ & & & -67.3 & 343.0 & 4.6 & 2.00 & 942.0 & 78.2 & 174.7 \\
\hline $\mathrm{CLO03}$ & $8 / 8$ & Oline & 3 & -66.0 & 352.7 & 1.6 & 7.99 & 1149.6 & 84.8 & 176.4 \\
\hline CL008 & $6 / 7$ & Oline & 3 & 58.6 & 160.3 & 3.5 & 5.99 & 359.3 & -73.9 & 37.8 \\
\hline CLO09 & $7 / 7$ & 'Aline & 3 & 80.4 & 153.7 & 4.4 & 6.97 & 189.3 & -62.3 & 305.8 \\
\hline CLO10 & $8 / 8$ & $\mathrm{AF}=20$ & & 79.1 & 171.7 & 2.3 & 7.99 & 594.3 & -67.3 & 295.9 \\
\hline CLO11 & $7 / 7$ & Oline & 3 & 79.4 & 167.9 & 2.4 & 6.99 & 652.7 & -66.3 & 298.7 \\
\hline \multirow[t]{2}{*}{ CLO12 } & $8 / 8$ & $\mathrm{AF}=30$ & & 81.4 & 181.3 & 2.5 & 7.99 & 486.4 & -63.5 & 287.3 \\
\hline & $4^{*}$ & & & 80.2 & 168.5 & 2.5 & 4.00 & 1405.1 & -65.0 & 297.0 \\
\hline CL013 & $7 / 7$ & $\mathrm{AF}=20$ & & -64.3 & 355.4 & 2.0 & 6.99 & 947.2 & 86.8 & 204.4 \\
\hline \multirow[t]{2}{*}{ CL014 } & $8 / 8$ & Anch & 3 & -65.3 & 356.9 & 2.0 & 7.99 & 802.1 & 87.7 & 177.4 \\
\hline & $2^{*}$ & & & -64.8 & 356.1 & 2.0 & 2.00 & 10394.0 & 87.3 & 193.4 \\
\hline CL015 & $7 / 8$ & $A F=30$ & & -57.3 & 356.1 & 3.7 & 6.98 & 266.0 & 80.9 & 268.3 \\
\hline
\end{tabular}

Site, identification number for paleomagnetic site (individual flow). MN denotes sites from Morro Negro; RS indicates sites from Alto Rio Senguerr, BA indicates sites from Balmaceda locality; and CL indicates sites from Cerro Lápiz. Site indicated with \# was not used in determining paleomagnetic pole); $N / N_{0}$, number of samples used to determine site-mean direction divided by number of samples demagnetized; Demag, type of analysis used to determine sample ChRM directions (e.g., AF $=30$ indicates that sample ChRM directions at $30 \mathrm{mT}$ peak altemating field were used; Aline and Oline indicate that principal component analysis line fits were performed on multiple step AF demagnetization data employing the anchored or origin options, respectively); $N^{\prime}$, number of demagnetization steps used in principal component analysis line fits; $I_{m}$ and $D_{m}$, site-mean inclination and declination, respectively; $\alpha_{95}$, radius of cone of $95 \%$ confidence about the site-mean direction; $R$, length of vector resultant of $N$ unit vectors; $k$, best estimate of Fisher precision parameter; $\lambda_{\mathrm{p}}$ and $\phi_{\mathrm{p}}$, site-mean VGP latitude and longitude, respectively.

* indicates that the preceding five sites (or other number indicated) in stratigraphic succession were found to have statistically indistinguishable site-mean directions, and those site-mean directions have been averaged to yield the "cooling unit" mean listed.

well-determined ChRM directions. One site from Morro Negro (MN016) was rejected because no samples yielded satisfactorily determined ChRM directions. Twelve samples distributed among the remaining sites were rejected because their directions were removed from the calculated site-mean ChRM by more than two estimated angular standard deviations. Site-mean ChRM directions were recalculated following rejection of these samples. Although listed in Table 2, the sitemean ChRM direction from site BA006 has anomalously low $k$ and large $\alpha_{95}$ and is not considered further. Given initial concerns about lightning-struck outcrops, the number of samples and sites rejected was quite small.

\section{ANALYSIS of PaLEOMAgNETIC Directions}

\section{Statistical Independence of Site-Mean Directions}

A standard procedure for analysis of paleomagnetic data is to use a set of site-mean VGPs to calculate a paleomagnetic pole. However, within the sampled sections from the Patagonian plateau basalts, there are groups of stratigraphically superposed flows with indistinguishable site-mean ChRM directions (hereafter referred to simply as site-mean directions). These groups of flows probably erupted within a time interval which was short compared to the dominant periods of geomagnetic secular variation. Thus the number of flows exceeds the number of independent samplings of the paleomagnetic field. Using all site-mean ChRM directions would bias the resulting paleomagnetic pole toward the VGPs of these rapidly extruded flows and would overestimate the precision of the resultant pole.

To deal with this problem, we used the procedure of Calderone et al. [1990]. Site-mean directions from stratigraphically adjacent flows were compared using the method of McFadden and Lowes [1981] to determine whether the directions are statistically distinguishable at the $95 \%$ confidence level. We apply the term "cooling unit" to either (1) groups of flows with statistically indistinguishable site-mean direc- 
tions representing a single sampling of the paleomagnetic field or (2) single flows with site-mean directions which are statistically distinguishable from those of stratigraphically adjacent flows.

The ChRM direction and VGP for cooling units composed of several flows were calculated by averaging the site-mean directions within the cooling unit. For cooling units with $\geq 3$ site-mean directions, statistics were determined by treating each site-mean direction as a unit vector. For cooling units with only two site-mean directions, statistics of the least precise site-mean direction were used for cooling-unit statistics.
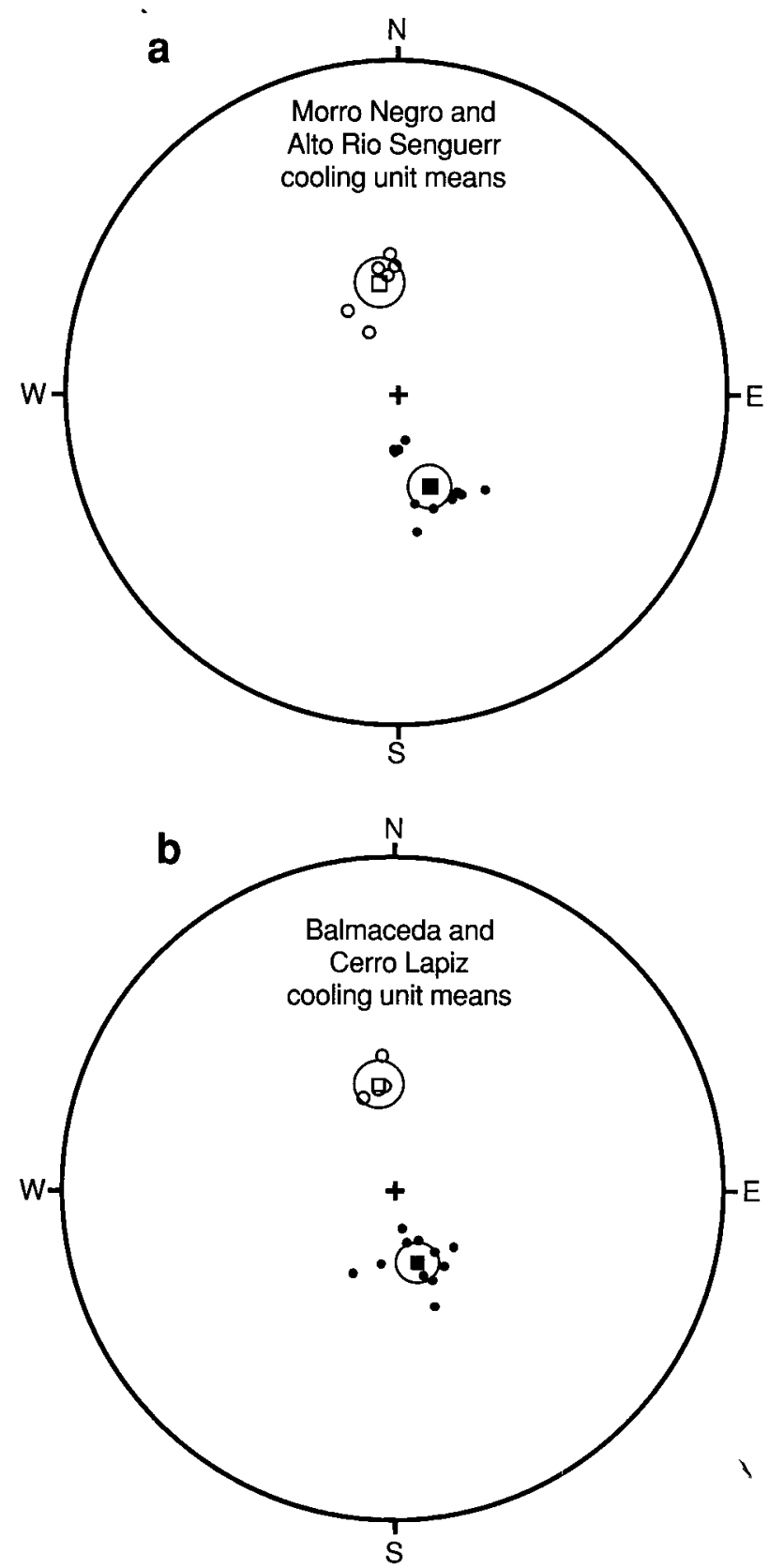

Fig. 6. Equal-area projections of cooling-unit mean directions of characteristic NRM (ChRM). Directions on the lower hemisphere are shown by solid circles, while directions on the upper hemisphere are shown by open circles. (a) Cooling-unit ChRM directions from Morro Negro and Alto Rio Senguerr. (b) Cooling-unit ChRM directions from Balmaceda and Cerro Lápiz. The mean directions of the normal-polarity cooling units are shown by the open squares, while mean directions for reversed-polarity cooling units are shown by the solid squares. Circles surrounding the mean directions are $95 \%$ confidence limits.
The cooling-unit mean directions and attendant statistics are listed in Table 2.

The 21 site-mean directions from Morro Negro reduced to 11 cooling units; 17 site-mean directions from Alto Rio Senguerr yielded seven cooling units; 11 site-mean directions from both Balmaceda and Cerro Lápiz reduced to nine and six cooling units, respectively. These cooling-unit directions and VGPs can reasonably be treated as independent samplings of the paleomagnetic field, whereas many site-mean directions are demonstrably not independent.

For determination of paleomagnetic poles, the data were analyzed in two age groupings: (1) a Late Cretaceous group including the data from Morro Negro and Alto Rio Senguerr for which $\mathrm{K} / \mathrm{Ar}$ results indicate an age range of $\sim 69$ to $79 \mathrm{Ma}$; (2) an Eocene group including data from Balmaceda and Cerro Lápiz with $\mathrm{K} / \mathrm{Ar}$ dates in the $42-56 \mathrm{Ma}$ range.

For the Late Cretaceous group, there are 18 cooling-unit directions: six normal polarity and 12 reversed polarity (Figure 6a). The technique of McFadden and Lowes [1981] was used to evaluate the reversals test. The antipode of the mean of the 12 reversed-polarity directions is not distinguishable at $95 \%$ confidence (5\% significance level) from the mean of the six normal-polarity directions. This "passage of the reversals test" indicates that no significant unremoved secondary NRM components are present in the ChRM directions. The positive reversals test also suggests that geomagnetic secular variation during both normal-polarity and reversed-polarity intervals has been adequately sampled by the 18 cooling-unit directions. A paleomagnetic pole for the Late Cretaceous group was determined by calculating the average of the 18 cooling-unit VGPs. This pole and attendant statistics are listed in Table 3.

The Eocene group contains 15 cooling-unit directions; four normal polarity and 11 reversed polarity (Figure $6 b$ ). The antipode of the mean of the 11 reversed-polarity directions is $8.1^{\circ}$ removed from the mean of the four normalpolarity directions. Application of the McFadden and Lowes [1981] test indicates that this difference is significant at the $95 \%$ confidence level but not at the $99 \%$ confidence level. At face value, this result constitutes failure of the reversals test. Also the normal-polarity cooling-unit directions are tightly clustered ( $k=139$ compared with $k=30$ for reversed-polarity directions). These observations indicate that geomagnetic secular variation during normal polarity has probably not been adequately sampled. Averaging the 15 cooling-unit VGPs from the Eocene group yields an average VGP position: latitude $=78.0^{\circ} \mathrm{S}$; longitude $=336.5^{\circ} \mathrm{E}(N=15 ; R=14.58$; $A_{95}=6.7^{\circ}$ ). But the adequacy of the paleomagnetic data from the Eocene units for determination of a paleomagnetic pole is questionable. Because of failure of the reversals test and other problems discussed below, we conclude that these data are insufficient for determination of an Eocene paleomagnetic pole for South America.

\section{Averaging of Geomagnetic Secular Variation}

To evaluate whether geomagnetic secular variation has been adequately sampled, the following analyses were performed on the cooling-unit VGP data set from the Late Cretaceous flows of the Patagonian plateau basalts:

1. The $\chi^{2}$ tests of McFadden [1980a] were used to compare the radial and azimuthal distribution of VGPs with the Fisher distribution. The Late Cretaceous/Paleocene and the Eocene data set has VGP distribution which does not deviate from a Fisherian distribution at the $5 \%$ significance level.

2. The angular dispersion of the VGP data set (estimated angular standard deviation) was compared with the global compilation of paleosecular variation presented by McFadden and McElhinny [1984]. Because the cooling-unit directions 
TABLE 3. Mean Direction and Paleomagnetic Pole from Late Cretaceous Units of the Patagonian Plateau Basalts

\begin{tabular}{|c|c|c|c|c|c|c|c|c|c|c|c|}
\hline \multicolumn{6}{|c|}{ Mean direction } & & \multicolumn{5}{|c|}{ Paleomagnetic pole } \\
\hline$N$ & $\begin{array}{c}I, \\
\operatorname{deg}\end{array}$ & $\begin{array}{c}D, \\
\operatorname{deg}\end{array}$ & $R$ & $k$ & $\begin{array}{l}\alpha_{95} \\
\operatorname{deg}\end{array}$ & & $\begin{array}{l}\text { Lat, } \\
{ }^{\circ} \mathrm{N}\end{array}$ & $\begin{array}{l}\text { Long, } \\
{ }^{\circ} \mathrm{E}\end{array}$ & $R$ & $K$ & $\begin{array}{r}A_{95} \\
\text { deg }\end{array}$ \\
\hline 18 & 65.1 & 43.8 & 17.75 & 66.81 & 4.0 & $s$ & $\begin{array}{l}78.7 \\
78.7^{*}\end{array}$ & $\begin{array}{l}178.4 \\
358.4^{*}\end{array}$ & 17.46 & 31.55 & 6.3 \\
\hline
\end{tabular}

$N$, number of cooling units; $I$, mean inclination; $D$, mean declination; $R$, length of resultant of $N$ unit vectors; $k(K)$, estimate of Fisher's precision parameter for directions (VGPs); $\alpha_{95}\left(A_{95}\right)$, radius of cone of $95 \%$ confidence about mean direction (pole); Lat, latitude of mean pole position; Long, longitude of mean pole position.

*Antipode.

and VGPs are determined with high precision, the contribution to total VGP dispersion from dispersion within cooling units was found negligible. The method of $\operatorname{Cox}$ [1969] was used to determine $95 \%$ confidence limits for the VGP angulat dispersion. The VGP angular dispersion for the Late Cretaceous data set is $S=14.5^{\circ}$ with $95 \%$ confidence limits of $18.7^{\circ}$ and $11.8^{\circ}$. In Figure 7 , the VGP angular dispersion from the Late Cretaceous Patagonian plateau basalts is compared with results of the global compilation for the 45-110 $\mathrm{Ma}$ age range. From Figure 7 , it is evident that the observed VGP angular dispersion has confidence limits which include the least squares fit to the 45-110 Ma compilation.

$M c F$ adden [1980b] has developed inference tests for statistical comparison between the dispersions of a directional data

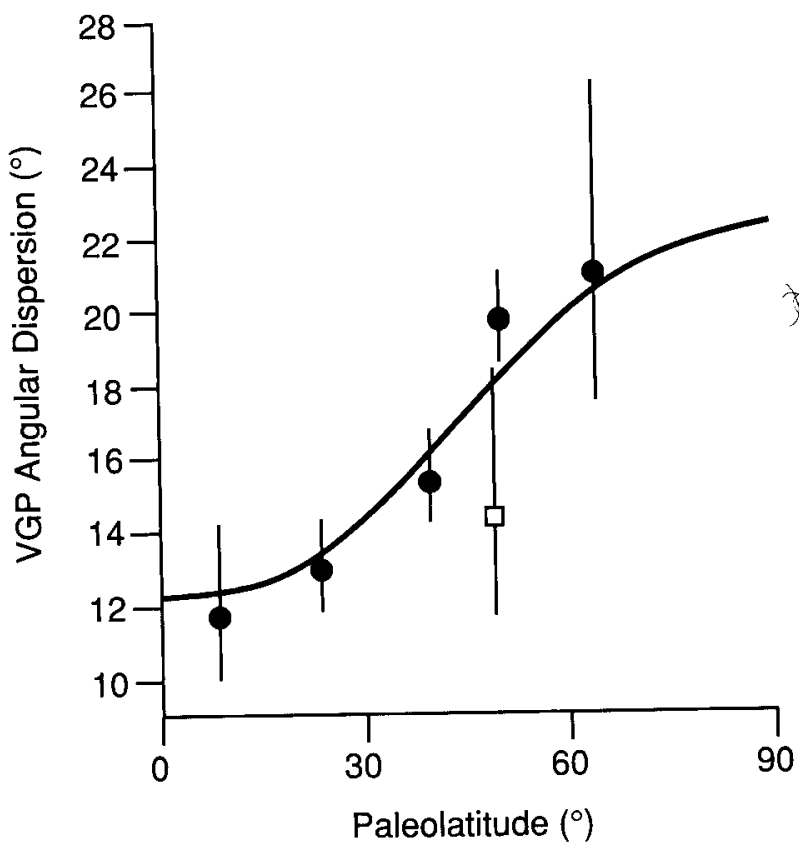

Fig. 7. Angular dispersions of virtual geomagnetic poles (VGPs) in 45-110 Ma global compilation of McFadden and McElhinny [1984] compared with VGP angular dispersion observed for the Late Cretaceous units of the Patagonian plateau basalts. VGP angular dispersions from the global compilation are shown by solid circles. VGP angular dispersion for Late Cretaceous units of the Patagonian plateau basalts is shown by the open square. Vertical lines indicate 95\% confidence limits for each datum. Curve is the least squares fit to the global compilations. set (or set of VGPs) and a distribution with known dispersion. If the least squares fit to the 45-110 Ma global compilation is treated as a known distribution (the curve of Figure 7 is presumed known without error), it is possible to use McFadden's [1980b] two one-tailed tests to determine whether the observed VGP angular dispersion significantly deviates from the model of paleosecular variation. For the $\sim 50^{\circ} \mathrm{S}$ paleolatitude of the Patagonian plateau basalts, the VGP angular dispersion predicted by the $45-110 \mathrm{Ma}$ model is $\sim 18^{\circ}$. Using this value and the number of cooling units in the VGP data set, upper and lower $95 \%$ confidence limits for VGP angular dispersion were calculated [McFadden, 1980, equations 4 and 5] and are listed in Table 4. The Late Cretaceous data set has VGP angular dispersion indistinguishable from the 45 $110 \mathrm{Ma}$ model at $95 \%$ confidence. There is no reason to doubt that the Late Cretaceous units have adequately sampled geomagnetic secular variation. We thus believe that the paleomagnetic pole determined from the Late Cretaceous data set is a reliable and robust pole.

\section{DiSCUSSION AND CONCLUSIONS}

The basic result of this investigation is the paleomagnetic pole from the Late Cretaceous units shown in Figure 8 and listed in Table 3. This paleomagnetic pole was determined by detailed analysis of samples from 38 flows which yielded 18 independent samplings of the geomagnetic field. A positive reversals test and VGP angular dispersion consistent with sampling of geomagnetic secular variation indicate that secular variation has been adequately averaged. Although previously available paleomagnetic poles for the Late Cretaceous

TABLE 4. Comparisons of VGP Dispersions With Global Compilations .

\begin{tabular}{ccccc}
\hline Data Set & $N^{\prime}$ & $\begin{array}{c}S_{1}, \\
\mathrm{deg}\end{array}$ & $\begin{array}{c}S, \\
\mathrm{deg}\end{array}$ & $\begin{array}{r}S_{\mathrm{u}} \\
\mathrm{deg}\end{array}$ \\
\hline $\begin{array}{l}\text { Late Cretaceous VGPs } \\
\text { PSV model for 45-110 Ma }\end{array}$ & 18 & & 14.5 & \\
\hline
\end{tabular}

$N$, number of VGPs used to determine dispersion statistics; $S$, estimated angular standard deviation; PSV model value of $S=18^{\circ}$ is from McFadden and McElhinny's [1984] least squares fit to global compilation for 45-110 Ma age range; $S_{1}$ and $S_{\mathrm{u}}$ are lower and upper 95\% confidence limits for $S$ calculated by method of McFadden [1980b]. 
TABLE 5. Comparisons of Patagonian Plateau Basalts Paleomagnetic Pole With Late Cretaceous and Early Tertiary Paleomagnetic Poles From Africa and North America

\begin{tabular}{|c|c|c|c|c|c|}
\hline & $N$ & $\begin{array}{l}\text { Lat, } \\
{ }^{\circ} \mathrm{N}\end{array}$ & $\begin{array}{l}\text { Long, } \\
{ }^{\circ} \mathrm{E}\end{array}$ & $\begin{array}{c}A_{95} \\
\text { deg }\end{array}$ & Source \\
\hline \multicolumn{6}{|l|}{ North American paleomagnetic poles } \\
\hline Cretaceous & 4 & 71.1 & 195.7 & 4.9 & 1 \\
\hline Paleocene & 6 & 78.7 & 185.1 & $\#$ & 2 \\
\hline $\begin{array}{l}\text { Patagonian Basalts Late Cretaceous pole } \\
\text { reconstructed to } 70 \mathrm{Ma} \text { position relative } \\
\text { to fixed North Americas }\end{array}$ & 1 & 70.8 & 196.1 & 6.3 & \\
\hline \multicolumn{6}{|l|}{ African paleomagnetic poles } \\
\hline Late Cretaceous poles & 1 & -63.5 & 39.6 & 4.1 & 3 \\
\hline & 1 & -64.1 & 46.1 & 5.2 & 4 \\
\hline & 1 & -69.1 & 60.0 & 4.9 & 3 \\
\hline & 1 & -68.8 & 40.8 & 4.4 & 5 \\
\hline Mean pole & 4 & -66.6 & 46.2 & 5.3 & \\
\hline Eocene & 1 & -69.0 & 9.0 & 5.8 & 6 \\
\hline $\begin{array}{l}\text { Patagonian Basalts Late Cretaceous pole } \\
\text { reconstructed to } 71.4 \mathrm{Ma} \text { position relative } \\
\text { to fixed Africa } \dagger\end{array}$ & 1 & -68.6 & 45.6 & 6.3 & \\
\hline
\end{tabular}

$N$, number of paleomagnetic poles used to determine mean pole; $A_{95}$, radius of cone of $95 \%$ confidence about mean pole; references: 1, Globerman and Irving [1988]; 2, Gordon [1984]; 3, 75 Ma volcanic rocks and $\sim 90 \mathrm{Ma}$ volcanic rocks from Madagascar [McElhinny and Cowley, 1978]; 4, Kimberlite pole 1 (83-101 Ma) [Hargraves, 1989]; 5, Fuerteventura lavas [Storetvedt et al., 1979]; 6, Hussain et al. [1979].

\# ellipse of $95 \%$ confidence has $6^{\circ}$ semimajor axis striking $105^{\circ}$ clockwise from north and $3.7^{\circ}$ semiminor axis.

Finite rotation: $9.04^{\circ}$ counterclockwise about Lat $=8.52^{\circ} \mathrm{N}$, Long $=306.82^{\circ} \mathrm{E}$.

$f$ Finite rotation: $26.6^{\circ}$ counterclockwise about Lat $=63.0^{\circ} \mathrm{N}$, Long $=326.5^{\circ} \mathrm{E}$.

of South America formed a loose grouping about the present rotation axis, the Late Cretaceous paleomagnetic pole from the Patagonian plateau basalts is significantly removed from the rotation axis. This difference is probably the result of

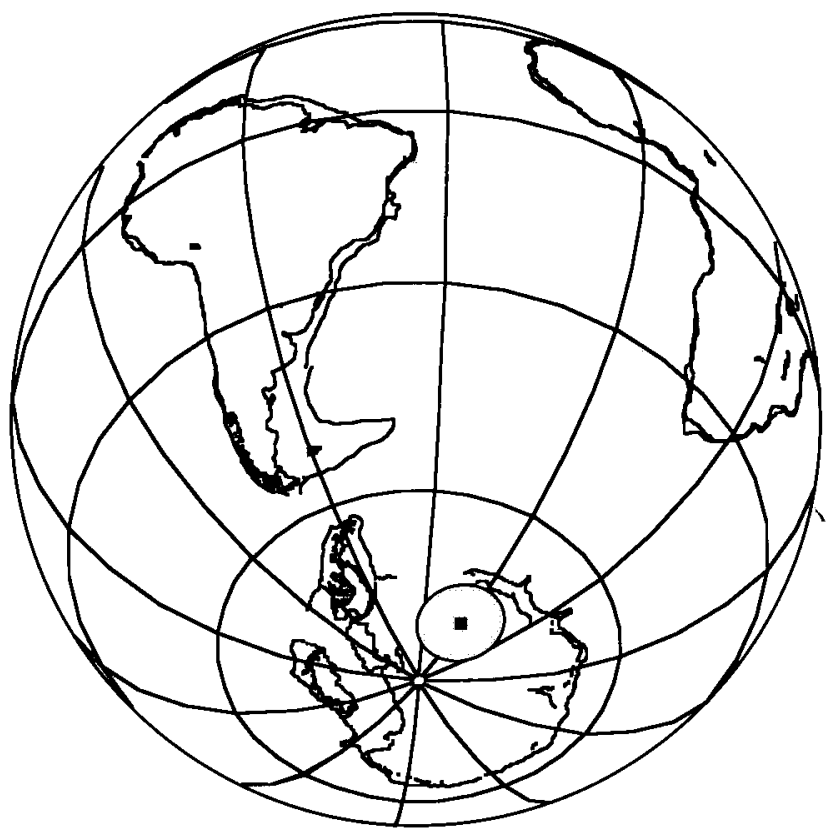

Fig. 8. Orthographic projection of paleomagnetic pole from the Late Cretaceous units of the Patagonian plateau basalts. Stippled oval surrounding pole is the $95 \%$ confidence region. inadequate sampling of geomagnetic secular variation (and perhaps insufficient demagnetization procedures) in the previous paleomagnetic studies.

We agree with the assertion by Besse and Courtillot [1988] that the finite relative rotations of major lithospheric plates back to the Late Cretaceous are known to better precision than are APW paths of those plates. The reliability of the Late Cretaceous paleomagnetic pole from the Patagonian plateau basalts thus can be further tested by comparison with paleomagnetic poles of similar age from North America and Africa.

We used the finite rotations determined by Klitgord and Schouten [1986] and Cande et al. [1988] to close the Atlantic Ocean to its $70 \mathrm{Ma}$ configuration. Required finite rotation poles and angles are given in Table 5. The Late Cretaceous paleomagnetic pole from the Patagonian plateau basalts has been rotated into a fixed North America frame and is shown in Figure $9 a$ and listed in Table 5. This rotated $\sim 70 \mathrm{Ma}$ pole for South America is indistinguishable from the mid-Cretaceous reference pole for North America [Globerman and Irving, 1988] and is located slightly towards the North American Paleocene reference pole [Gordon, 1984]. Thus the Late Cretaceous pole from the Patagonian plateau basalts is consistent with Cretaceous and Paleocene paleomagnetic poles from North America and with paleogeographic reconstructions of the Atlantic Ocean. This result is of major significance because the previously available paleomagnetic poles from the Late Cretaceous of South America were not consistent with the North American APW path and seafloor spreading history of the Atlantic.

The Late Cretaceous paleomagnetic pole from the Patagonian plateau basalts has also been rotated into a fixed Africa frame (Figure $9 b$ and Table 5). A Late Cretaceous 

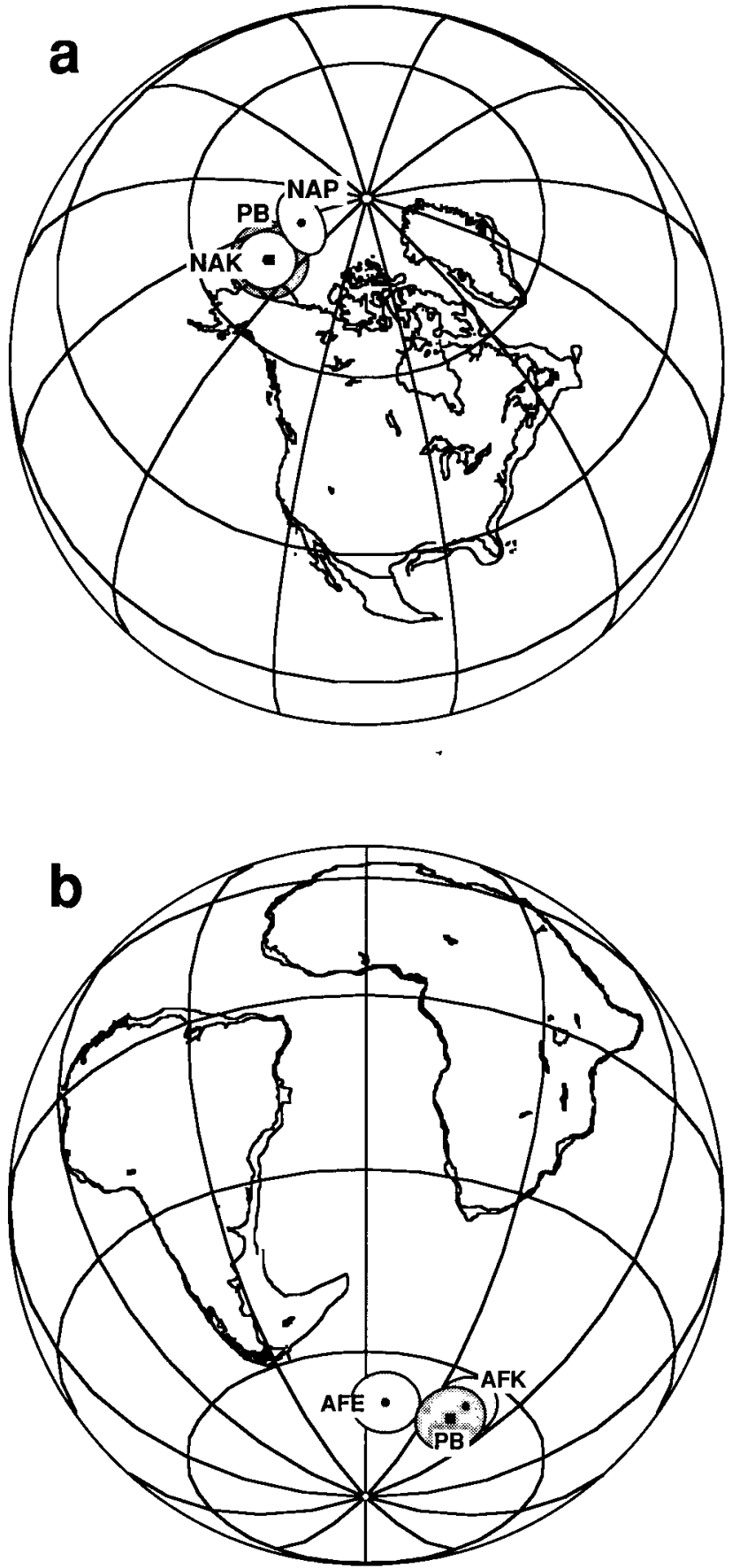

Fig. 9. Comparison of Late Cretaceous paleomagnetic pole from Patagonian plateau basalts with similar age poles from North America and Africa. Late Cretaceous pole from the Patagonian plateau basalts (labeled PB) is shown in both figures by the square with surrounding $95 \%$ confidence limits indicated by heavy stippled region. Grid of latitude and longitude is shown in intervals of $30^{\circ}$. (a) North American mid-Cretaceous pole is labeled NAK; Paleocene pole for North America is indicated by NAP; lightly stippled regions surrounding each pole are $95 \%$ confidence limits. Paleomagnetic pole from the Late Cretaceous units of the Patagonian plateau basalts has been reconstructed to fixed North American reference frame by closing the Atlantic to $70 \mathrm{Ma}$ position. (b) African Late Cretaceous pole is labeled AFK; Eocene pole for Africa is indicated by AFE; lightly stippled regions surrounding each pole are $95 \%$ confidence limits. Paleomagnetic pole from the Late Cretaceous units of the Patagonian plateau basalts has been reconstructed to fixed Africa reference frame by closing the Atlantic to $71 \mathrm{Ma}$ position. African and North American paleomagnetic poles and references are listed in Table 5. paleomagnetic pole was determined for Africa and is listed in Table 5. This pole is indistinguishable at $95 \%$ confidence from Late Cretaceous African poles determined by Tauxe et al. [1983] or Besse and Courtillot [1988] but incorporates more recently available data. The rotated $\sim 70 \mathrm{Ma}$ pole for South America is indistinguishable from the Late Cretaceous reference pole for Africa and is located approximately on a path from the African Late Cretaceous pole toward the Eocene pole for Africa [Hussain et al., 1979]. (No Paleocene paleomagnetic poles are available from Africa.) The Late Cretaceous pole from the Patagonian plateau basalts thus is consistent with the African APW path and paleogeographic reconstructions of the South Atlantic.

We conclude that the Late Cretaceous pole from the Patagonian plateau basalts provides a reliable paleomagnetic pole determination for South America. This paleomagnetic pole should replace previous Late Cretaceous poles (discussed in introduction) in analyses of South American apparent polar wander. The paleomagnetic pole from the Late Cretaceous units of the Patagonian plateau basalts should also be used as the reference pole when analyzing Late Cretaceous or Paleocene paleomagnetic data from South American orogenic zones.

Despite detailed analysis of samples from 27 Eocene volcanic flows of the Patagonian plateau basalts, the data do not provide a reliable determination of the Eocene paleomagnetic pole for South America. The 27 flows yielded 15 independent samplings of the geomagnetic field. But the data fail the reversals test and probably do not provide adequate sampling of geomagnetic secular variation. A further observation is that the average VGP position calculated from the 15 coolingunit VGPs of the Eocene data set is not consistent with the Eocene North American paleomagnetic pole [Diehl et al., 1983] when the Atlantic is reconstructed to $50 \mathrm{Ma}$. It is worth noting that a less rigorous analysis might not have revealed the inadequacies of these data for determination of an Eocene paleomagnetic pole. If additional paleomagnetic data are acquired from Eocene units of stable South America, inclusion of the cooling-unit VGPs from the Patagonian plateau basalts may yield a reliable Eocene pole for South America.

Paleomagnetic study of the Patagonian plateau basalts has allowed determination of a reliable Late Cretaceous pole for South America. This pole is significantly removed from the present rotation axis by $11^{\circ}$ of arc. Significant APW must occur between $\sim 70 \mathrm{Ma}$ and $10 \mathrm{Ma}$ when the paleomagnetic pole is indistinguishable from the present rotation axis. However, details of the Tertiary APW path for South America remain undetermined.

Acknowledgments. This research was funded by National Science Foundation Division of Earth Sciences grant EAR-8718016. We thank Alfredo Garcia for assistance in the field, Joaquin Ruiz for assistance with translations, and Dave Engebretson for assistance with the finite rotation calculations. The assistance of Cori Hoag and Steve Vasas with the paleomagnetic laboratory measurements is gratefully acknowledged. Reviews by Wulf Gose and Peter Plumley led to clarification of portions of the manuscript. We especially thank Alejandro Godoy and his family for logistical support and assistance in the field without which this project could not have been done.

\section{REFERENCES}

Baker, P. E., W. J. Rea, J. Skarmeta, R. Caminos, and D. C. Rex, Igneous history of the Andean Cordillera and Patagonia around latitude $46^{\circ}$ S, Philos. Trans. R. Soc. London, Ser. A, 303, 105 $149,1981$.

Beck, M. E., Jr., Discordant paleomagnetic pole positions as evidence of regional shear in the westem Cordillera of North America, Am. J. Sci., 276, 694-712, 1976.

Beck, M. E., Jr., Paleomagnetic record of plate-margin tectonic pro- 
cesses along the western margin of North America, J. Geophys. Res., 84, 7115-7131, 1980.

Beck, M. E., Jr., Analysis of Late Jurassic-Recent paleomagnetic data from active plate margins of South America, Jour. South Amer. Earth Sci., 1, 39-52, 1989.

Beck, M. E., Jr., R. E. Drake, and R. F. Butler, Paleomagnetism of Cretaceous volcanic rocks from central Chile and implications for the tectonics of the Andes, Geology, 14, 132-136, 1986.

Bellieni, G., P. Brotzu, P. Comin-Chairamonti, M. Emesto, A. F. Melfi, I. G. Pacca, E. M. Picirillo, and D. Stolfa, Petrological and paleomagnetic data on the plateau basalt and thyolite sequences of the southern Parana basin (Brazil), An. Acad. Bras. Cienc., 55, $355-383,1983$.

Besse, J., and V. Courtillot, Paleogeographic maps of the continents bordering the Indian Ocean since the Early Jurassic, J. Geophys. Res., 93, 11,791-11,808, 1988.

Cande, S., J. LaBrecque, and W. Haxby, Plate kinematics of the South Atlantic: Chron C34 to present, J. Geophys. Res., 93, 13,479$13,492,1988$.

Calderone, G. J., R. F. Butler, and G. D. Acton, Paleomagnetism of middle Miocene volcanic rocks in the Mojave-Sonora Desert region of western Arizona and southeastern California, $J$. Geophys. Res., 95, 625-247, 1990.

Charrier, R., E. Linares, H. Niemayer, and J. Skarmeta, Edades K-Ar de vulcanitas Mesozoicas y Cenozoicas del sector chileno de la Meseta Buenos Aires, Chile y su significado geológico, Actas 7th Congr. Geol. Arg., 2, 22-41, 1978.

Charrier, R., E. Linares, H. Niemayer, and J. Skarmeta, K-Ar ages of basalt flows of Meseta Nuenos Aireas in southern Chile and their relation to the southeast Pacific triple junction, Geology, 7, 436439. 1979.

Cox, A., Confidence limits for the precision parameter K, Geophys. J. R. Astron. Soc., 17, 545-549, 1969.

Diehl, J. F., M. E. Beck, Jr., S. Beske-Diehl, D. Jacobson, and B. C. Hearn, Paleomagnetism of the Late Cretaceous-Early Tertiary north central Montana alkalic province, J. Geophys. Res., 88, $10,593-10,609,1983$

Dunlop, D. J., Magnetic mineralogy of unheated and heated red sediments by coercivity spectrum analysis, Geophys. J. R. Astron. Soc., 27, 37-55, 1972.

Fisher, R. A., Dispersion on a sphere, Proc. R. Soc. London, Ser. A, 217, 295-305, 1953.

Galbrun, B., and R. F. Butler, Curie temperature analyses of Upper Jurassic and Lower Cretaceous pelagic limestones, Geophys. J. $R$. Astron. Soc., 86, 885-892, 1986.

Globerman, B. R., and E. Irving, Mid-Cretaceous paleomagnetic reference field for North America: Restudy of $100 \mathrm{Ma}$ intrusive rocks from Arkansas, J. Geophys. Res., 93, 11,721-11,733, 1988.

Gordon, R. G., A Paleocene North American paleomagnetic pole incorporating declination-only data, Geophys. Res. Lett., 11, 477-480, 1984.

Gordon, R. G., and D. M. Jurdy, Cenozoic global plate motions, $J$. Geophys. Res., 91, 12,389-12,406, 1986.

Gordon, R. G., and R. A. Livermore, Apparent polar wander of the mean-lithosphere reference frame, Geophys. J. R. Astron. Soc., 91, 1049-1057, 1987.

Gordon, R. G., A. Cox, and S. O'Hare, Paleomagnetic Euler poles, apparent polar wander, and absolute motion of North America since the Carboniferous, Tectonics, 3, 499-537, 1984.

Hargraves, R. B., Paleomagnetism of Mesozoic Kimberlites in southern Africa and the Cretaceous apparent polar wander curve for Africa, J. Geophys. Res., 94, 1851-1866, 1989.

Harrison, C. G. A., and T. Lindh, A polar wandering curve for North America during the Mesozoic and Cenozoic, J. Geophys. Res., 87, 1903-1920, 1982.

Hillhouse, J. W., Paleomagnetism of the Triassic Nikolai Greenstone, McCarthy quadrangle, Alaska, Can. J. Earth Sci., 14, 2578-2592, 1977.

Hussain, A. G., A. Schult, and H. Soffel, Paleomagnetism of basalts of Wadi Abu Tereifiya, Mandisha and dioritic dikes of Wadi Abu Shihat, Egypt, Geophys. J. R. Astron. Soc., 56, 55-61, 1979.

Irving, E., Paleopoles and paleolatitudes of North America and speculations about displaced terrains, Can. J. Earth Sci., 16, 669-694, 1979.

Irving, E., and G. A. Irving, Apparent polar wander paths Carboniferous through Cenozoic and the assembly of Gondwana, Geophys. Surv., 5, 141-188, 1982.
Irwin, J. J., W. D. Sharp, R. R. Spangler, and R. E. Drake, Some paleomagnetic constraints on the tectonic evolution of the Coastal Cordillera of central Chile, J. Geophys. Res., 92, 36033614, 1987.

Kirschvink, J. L. The least-squares line and plane and the analysis of palaeomagnetic data, Geophys. I. Roy. Astron. Soc., 62, 699718,1980 .

Klitgord, K., and H. Schouten, Plate kinematics of the central Atlantic, in The Geology of North America, vol. M, The Western North Atlantic Region, edited by P. R. Vogt and B. E. Tucholke, pp. 351-378, Geological Society of America, Boulder, Colo., 1986.

Kono, M., K. Heki, Y. Hamano, Paleomagnetic study of the central Andes: Counterclockwise rotation of the Peruvian block, $J$. Geodyn., 2, 193-2096, 1985.

Livermore, R. A., F. J. Vine, and A. G. Smith, Plate motions and the geomagnetic field-II, Jurassic to Tertiary, Geophys. J. R. Astron. Soc., 79, 939-961, 1984.

Lowrie, W., and F. Heller, Magnetic properties of marine limestones, Rev. Geophys., 20, 171-192, 1982.

McElhinny, M. W., and J. A. Cowley, Paleomagnetic directions and pole positions, XV, Pole numbers $15 / 1$ to $15 / 232$, Geophys. $J$. $R$. Astron. Soc., 52, 259-276, 1978.

McFadden, P. L.. The best estimate of Fisher's precision parameter $K$, Geophys. J. R. Astron. Soc., 60, 397-407, 1980a.

McFadden, P. L., Testing a palaeomagnetic study for the averaging of secular variation, Geophys. J. R. Astron. Soc., 61, 183-192, $1980 b$.

McFadden, P. L., and F. J. Lowes, The discrimination of mean directions drawn from Fisher distributions, Geophys. J. R. Astron. Soc., 67, 19-33, 1981.

McFadden, P. L., and M. W. McElhinny, A physical model for palaeosecular variation, Geophys. J. R. Astron. Soc., 78, 809$830,1984$.

Opdyke, N. D., and W. D. MacDonald, Paleomagnetism of the Late Cretaceous Pocos de Caldas alkalic complex of southern Brazil, Earth Planet. Sci. Lett., 18, 37-44, 1973.

Ramos, V. A., H. Niemayer, J. Skameta, and J. Muñoz, Magmatic evolution of the Austral Patagonia Andes, Earth Sci. Rev., 18, 411-443, 1982.

Schult, A., and S. D. C. Guerreiro, Paleomagnetism of Upper Cretaceous volcanic rocks from Cabo de St. Agostinho, Brazil, Earth Planet. Sci. Lett., 50, 311-315, 1980.

Steiger, R. H., and E. Jager, Subcommission on geochronology: Convention on the use of decay constants in geo- and cosmochronology, Earth Planet. Sci. Lett., 36, 359-362, 1977.

Storetvedt, K. M., A. M. Vaga, S. Aase, and R. Lovlie, Paleomagnetism and the early magmatic history of Fuerteventura (Canary Islands), "J. Geophys., 46, 319-334, 1979.

Tauxe, L., J. Besse, and J. L. LaBrecque, Palaeolatitudes from DSDP leg 73 sediment cores: Implications for the apparent polar wander path for Africa during the late Mesozoic and Cenozoic, Geophys. J. R. Astron. Soc., 73, 315-324, 1983.

Uliana, M. A., and K. T. Biddle, Permian to Late Cenozoic evolution of northern Patagonia: Main tectonic events, magmatic activity, and depositional trends, Gondwana Six: Structure, Tectonics, and Geophysics, Geophys. Mono. Ser., vol. 40, edited by G. D. McKenzie, pp. 271-286, AGU, Washington, D.C., 1987.

Valencio, D. A., J. E. Mendia, A. Giudici, and J. O. Gascon, Paleomagnetism of the Cretaceous Pirgua Subgroup (Argentina) and the age of opening of the South Atlantic, Geophys. J. R. Astron. Soc., 51, 47-58, 1977.

M. E. Beck, Jr. and R. F. Burmester, Department of Geology, Westem Washington University, Bellingham, WA 98225.

R. F. Butler, Department of Geosciences, University of Arizona, Tucson, AZ 85721

F. Hervé and F. Munizaga, Departamento de Geología y Geofísica, Universidad de Chile, Santiago, Chile.

E. S. Oviedo, Departamento de Ciencias Geologícas, Ciudad Universitaria, Buenos Aires, Argentina.

(Received June 4, 1990; revised November 16, 1990; accepted December 13, 1990.) 